\title{
The matrix revisited: A bird's-eye view of marine ecosystem service provision.
}

\author{
Daryl Burdon ${ }^{1 *}$, Tavis Potts ${ }^{2}$, Carol Barbone ${ }^{2}$, Lucas Mander ${ }^{1}$ \\ ${ }^{1}$ Institute of Estuarine \& Coastal Studies, University of Hull, Hull, UK HU6 7RX \\ ${ }^{2}$ School of Geosciences, University of Aberdeen, Aberdeen, UK AB24 3UF \\ *Corresponding author D. Burdon, D.Burdon@hull.ac.uk, 01482466786
}

\begin{abstract}
:
The marine environment provides a range of ecosystem services and benefits for society. A previous study in Marine Policy [1] advocated a matrix approach to demonstrate the relative degree of ecosystem service provision from habitats and species within UK Marine Protected Areas (MPAs), but excluded seabird species in its assessment. Despite the number of existing UK MPAs designated specifically for individual seabird species and/or seabird assemblages, and the fact that seabird species have long been used as policy-relevant indicators for the monitoring and management of the marine environment, as yet little research has focussed on the direct role of seabird species in the provision of ecosystem services and how these are captured for marine spatial planning purposes in the context of MPAs. Building on the matrix approach, this paper develops and populates a matrix to illustrate the relationship between key UK breeding seabird species and their relative contribution to the delivery of intermediate ecosystem services and goods/benefits. The original matrix approach has been strengthen to include the development and testing of a set of rules for combining multiple matrices. Confidence scores relating to the underlying evidence base are built into the matrix to provide an illustration of the current understanding and to identify current gaps in evidence. Following a sense check by external seabird experts the matrix is applied in the context of four existing UK MPA case study sites. Further developments and applications of the seabird matrix are discussed within the context of wider marine management.
\end{abstract}

\section{Research Highlights:}

- A seabird matrix was developed and populated for relative ecosystem service provision

- Rules were established and tested for combining scores from multiple matrices

- Confidence scores were applied to the evidence base underlying the assessment

- Application to case study sites demonstrates the value of applying a matrix approach

\section{Introduction}

There has been a growing interest in ecosystem services research since the work of Costanza et al. [2] who valued the world's ecosystem services and natural capital. One of the earliest definitions of ecosystem services was provided by Daily [3] who defined them as the 'conditions and processes through which natural ecosystems, and the species they include, sustain and fulfil human life' however to date there has been no agreed definition in the literature [4]. Following the work of Fisher et al. [5], Luisetti et al. [6] and Turner et al. [7] ecosystem services are defined here as 'the link between ecosystems and the benefits that they provide for society'. This definition recognises that ecosystem services are provided by natural ecosystems (both habitats and species), however for ecosystem services to be realised as a benefit for society, society must input built, human and/or social capital [7]. Fisher et al. [5] make a further distinction by stating that 'while most ecosystem structures and processes do provide services they are not the same thing' thus leading to a generic classification 
based around intermediate ecosystem services associated with indirect benefits, and final ecosystem services associated with direct benefits. This approach avoids any potential for double counting of benefits, which is particularly important when it comes to valuation [8]. In the UK, this distinction has been taken forward by the UK National Ecosystem Assessment (UKNEA) which focused on the processes that link human society and well-being to a wide range of terrestrial and aquatic habitats [9]. Although this generic ecosystem services framework was applied to both coastal margins and marine ecosystems, it was specifically modified for the marine environment under the NERC-funded Valuing Nature Network (VNN ${ }^{1}$ ) coastal management project [1] and workshops within the UK National Ecosystem Assessment Follow-On (UKNEAFO) project [10]. The final UKNEAFO framework is presented in Figure 1, with definitions of each intermediate ecosystem service and goods/benefits provided by UK seabird species being listed in Table 2 .

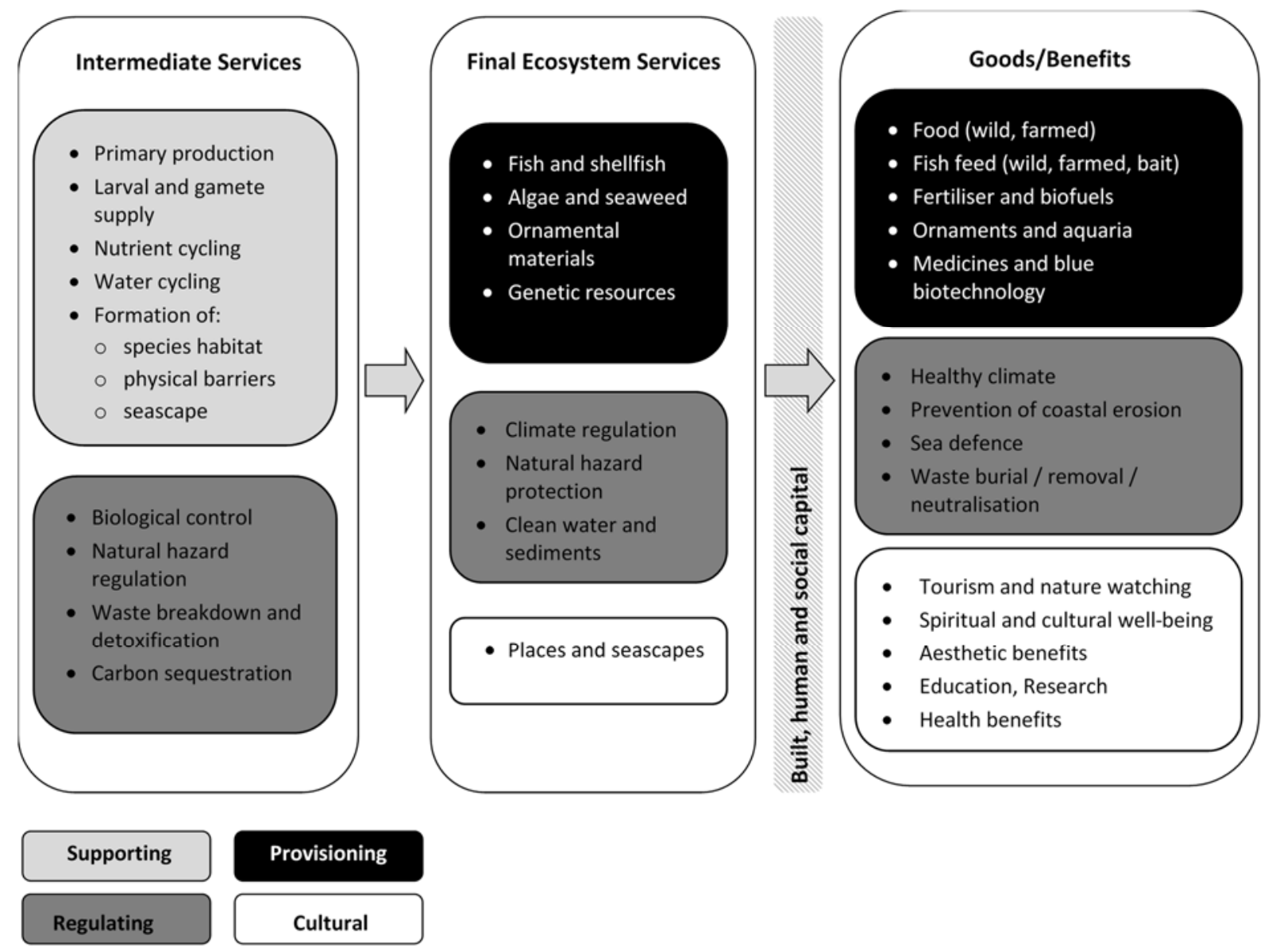

\section{Figure 1: The UK NEAFO ecosystem service framework [7]}

As part of the VNN programme, a desk-based study was undertaken to examine the potential relationships between the provision of coastal ecosystem services and the designation of Marine Protected Areas (MPAs) [1]. Their study, building on the earlier work of Fletcher et al. [11], identified the relative importance of a range of UK protected habitats and species in the provision of intermediate ecosystem services and goods/benefits. This structured assessment, based on evidence from the literature and expert opinion, enabled rapid assessments to be undertaken on the intermediate ecosystem services and goods/benefits provided by a range of existing UK MPAs. This approach was further developed by Saunders et al. [12] to include those habitats and species provided

\footnotetext{
${ }^{1}$ The Valuing Nature Network (VNN) aims to improve understanding of the value of nature both in economic and noneconomic terms, and improve the use of these valuations in decision making (http://valuing-nature.net/).
} 
in Northern Irish waters as well as to further developments of the ecosystem service framework including the incorporation of well-being and physical and psychological benefits from services [7]. Such an assessment provides a useful qualitative tool to assess wider benefits provided by existing and future MPAs. For example, the matrices for habitats and species have since been used by the Scottish Government to inform the consultation process underpinning the designation of marine conservation protected areas in Scotland [13]. Recently the approach was applied locally within the context of the Moray Firth as a test-bed for wider application with stakeholders in the regional marine planning process including consideration of pressures and resolution of conflicts, in line with the Scottish Government's sustainability agenda [14]. The matrices are also being developed for application to a series of MPAs off the Xiamen coast in China [15].

For the purposes of this paper, the authors define MPAs to include Special Areas of Conservation (SACs) under the EU Habitats and Species Directive (92/43/EEC), Marine Conservation Zones (MCZs) under the Marine and Coastal Access Act 2009, Nature Conservation MPAs under the Marine (Scotland) Act 2010, and MCZs under the Marine (Northern Ireland) Act 2013.

The species matrices presented in Potts et al. [1] and Saunders et al. [12] did not include seabird species. It is argued here that seabirds should have been included in the assessment as they are top marine predators and are policy-relevant indicators for the monitoring and management of the marine environment $[16,17]$. The value of seabirds as both qualitative and quantitative indicators has been discussed in the literature [18]. Top predator populations, such as seabirds, reflect the variation of lower trophic levels they depend on [19]. Therefore, demographic parameters such as breeding success are valuable as an ecological indicator of environmental changes and anthropogenic pressures [20]. In the context of the regulatory framework, Black-legged kittiwake (Rissa tridactyla) productivity, for example, is used as a state indicator as well as a target to monitor progress towards achieving Good Environmental Status under the EU Marine Strategy Framework Directive (2008/56/EC). As well as being valuable ecological indicators of the health of the marine environment, seabirds have also been identified as key indicators of ecosystem service provision [21,22]. For example, the number and breeding success of Black-legged kittiwake at Skomer Marine Nature Reserve, Wales, has been proposed as appropriate indicators to identify the scale and trajectory of change in ecosystem service provision over time [21].

Within the UK, all four government administrations are committed to the shared vision of 'clean, healthy, safe productive and biologically diverse oceans and seas' and consider nature conservation to be an integral part of this vision. The UK Marine Policy Statement (2011) states that 'creating a UKwide ecologically coherent network of MPAs is a key element of its wider work to recover and conserve the richness of our marine environment and wildlife' [23]. Within the UK, all seabirds and seaducks (with the exception of the Black guillemot, Cepphus grille) must be accorded protection within Special Protection Areas (SPAs) under the EU Wild Birds Directive (2009/147/EC). In addition, the Black guillemot is protected under the national legislation of both Scotland and Northern Ireland. There are currently 102 SPAs which have marine components designated in the UK and therefore these sites form a large component of an ecologically coherent network of MPAs in the UK [24].

This paper develops and populates a matrix, based on an established methodology, to identify the relative provision of intermediate ecosystem services and goods/benefits by UK breeding seabird species. In order to strengthen the transparency of the methodology, this paper develops and tests a set of rules for combining multiple matrices. The final seabird matrix generated within this paper is applied to real-world MPA case study sites to demonstrate its potential to support management within designated sites, particularly in terms of identifying the diversity and importance of a range of ecosystem services. We argue that the matrix approach can support a wider discussion with policy, 
the private sector and civil society of the role and extent of societal benefits from nature, and in this case, seabirds in particular in line with international commitments in biodiversity policy. Despite its focus on UK breeding seabird species, the methodology and outcomes of this paper are of global relevance given the highly mobile nature of seabird species.

\section{Methodology}

The methodology employed here generally follows that presented in Saunders et al. [12] but with a focus on UK seabird species. A five-step process was followed: (1) Selection of UK seabird species to include in the matrix; (2) Definition of intermediate ecosystem services and goods/benefits provided by UK seabird species; (3) Population of UK seabird matrix; (4) Combination of multiple matrix assessments, and (5) Sense check and subsequent refinement of the matrix. Each of these steps are described in detail below.

\subsection{Selection of UK seabird species to include in the matrix}

The first challenge was to define which species to include within the matrix. A total of 106 bird species are known to use UK marine waters, of which 45 species are known to occur in numbers greater than 50 [25]. The number of species using UK marine waters varies seasonally: whilst there is a large influx of seaducks, divers and grebes in coastal waters in winter, a greater number of true marine seabirds use coastal areas/islands in the summer months to nest. There are more than seven million breeding pairs of true marine seabirds in the UK, which are comprised of 25 species in eight families [25]. SPAs in the UK have been designated at sea where high concentrations of these species occur. In addition, six of these species are on the UK Red list of conservation concern, because of their declining breeding numbers [26]. In order to develop the matrix in a manageable way and deal with the seabird assemblage that is most relevant to the designated MPAs, this paper focusses on this assemblage of 25 seabird species which depend on the UK marine environment for their survival, as defined by the Joint Nature Conservation Committee (JNCC) (Table1). Population data are available for all of these seabird species as they regularly breed in Britain and Ireland and thus form part of the JNCC Seabird Monitoring Programme [25].

Table 1: Seabird species selected for inclusion in the matrix. Breeding population data collected from the UK Seabird 2000 survey (1998-2002) [27].

\begin{tabular}{|c|c|c|c|c|}
\hline Common name & Scientific name & $\begin{array}{l}\text { Britain \& Ireland } \\
\text { breeding population } \\
\text { (Count Unit*) }\end{array}$ & $\begin{array}{l}\text { Key marine and coastal } \\
\text { nesting habitats }\end{array}$ & Foraging guilds \\
\hline Northern fulmar & Fulmarus glacialis & 537,991 (AOS) & $\begin{array}{l}\text { Cliff and rocky-ground } \\
\text { nester }\end{array}$ & Offshore surface-feeder \\
\hline Manx shearwater & Puffinus puffinus & 374,067 (AOS) & Island-ground nester & Offshore surface-feeder \\
\hline European storm-petrel & Hydrobates pelagicus & 100,025 (AOS) & Island-ground nester & Offshore surface-feeder \\
\hline Leach's storm-petrel & $\begin{array}{l}\text { Oceanodroma } \\
\text { leucorhoa }\end{array}$ & 48,357 (AOS) & Island-ground nester & Offshore surface-feeder \\
\hline Northern gannet & Morus bassanus & 259,311 (AOS/AON) & Cliff-nester & $\begin{array}{l}\text { Offshore sub-surface- } \\
\text { feeder }\end{array}$ \\
\hline Great cormorant & Phalacrocorax carbo & 13,628 (AON) & Cliff-nester & Inshore benthic feeder \\
\hline European shag & $\begin{array}{l}\text { Phalacrocorax } \\
\text { aristotelis }\end{array}$ & 32,306 (AON) & Cliff-nester & Inshore benthic feeder \\
\hline Arctic skua & Stercorarius parasiticus & 2,100 (AOT) & Flat-ground nester & Inshore surface-feeder \\
\hline Great skua & Catharacta skua & 9,635 (AOT) & Flat-ground nester & Inshore surface-feeder \\
\hline Black-legged kittiwake & Rissa tridactyla & 415,995 (AON) & Cliff-nester & Offshore surface-feeder \\
\hline Black-h & $\begin{array}{l}\text { Chroicocephalus } \\
\text { ridibundus }\end{array}$ & 79,392 (AON) & Flat-ground nester & Coast \\
\hline
\end{tabular}




\begin{tabular}{|c|c|c|c|c|}
\hline Mediterranean gull & Larus melanocephalus & $113(\mathrm{AON})$ & Flat-ground nester & Coastal omnivore \\
\hline Mew gull & Larus canus & 21,475 (AON) & Flat-ground nester & Coastal omnivores \\
\hline Lesser black-backed gull & Larus fuscus & 91,323 (AON) & $\begin{array}{l}\text { Cliff, flat-ground and } \\
\text { urban-nester }\end{array}$ & Coastal omnivore \\
\hline Herring gull & Larus argentatus & $147,114(\mathrm{AON})$ & $\begin{array}{l}\text { Cliff, flat-ground and } \\
\text { urban-nester }\end{array}$ & Coastal omnivore \\
\hline Great black-backed gull & Larus marinus & 19,691 (AON) & $\begin{array}{l}\text { Cliff and flat-ground } \\
\text { nester }\end{array}$ & Coastal omnivore \\
\hline Little tern & Sternula albifrons & $2,153(A O N)$ & Flat-ground nester & Inshore surface-feeder \\
\hline Sandwich tern & Sterna sandvicensis & 14,252 (AON) & Flat-ground nester & Inshore surface-feeder \\
\hline Common tern & Sterna hirundo & 14,497 (AON) & Flat-ground nester & Inshore surface-feeder \\
\hline Roseate tern & Sterna dougallii & 790 (AON) & Flat-ground nester & Inshore surface-feeder \\
\hline Arctic tern & Sterna paradisaea & 56,123 (AON) & Flat-ground nester & Inshore surface-feeder \\
\hline Common guillemot & Uria aalge & $1,559,484$ (IND) & Cliff-nester & $\begin{array}{l}\text { Offshore sub-surface- } \\
\text { feeder }\end{array}$ \\
\hline Razorbill & Alca torda & 216,087 (IND) & Cliff-nester & $\begin{array}{l}\text { Offshore sub-surface- } \\
\text { feeder }\end{array}$ \\
\hline Black guillemot & Cepphus grylle & 42,683 (IND) & Rocky-ground nester & $\begin{array}{l}\text { Inshore sub-surface- } \\
\text { feeder }\end{array}$ \\
\hline Atlantic puffin & Fratercula arctica & 600,751 (AOB) & $\begin{array}{l}\text { Cliff and island-ground } \\
\text { nester }\end{array}$ & $\begin{array}{l}\text { Offshore sub-surface- } \\
\text { feeder }\end{array}$ \\
\hline
\end{tabular}

* AOS=Apparently Occupied Site; AON=Apparently Occupied Nest; AOT=Apparently Occupied Territory; AOB=Apparently Occupied Burrows; IND=Individuals

\subsection{Definition of intermediate ecosystem services and goods/benefits provided by seabird species}

For consistency in approach [12], the UK NEAFO ecosystem service framework was used (Figure 1), with the assessment focussing on both intermediate ecosystem services and the goods/benefits they deliver for society. Separate rankings of the final ecosystem services (as identified in Figure 1) was deemed unnecessary as contributions are inherently captured through scoring goods/benefits and inclusion of further columns would reduce the clarity and manageability of the matrix and potentially build in double counting. Based on the definitions provided by Turner et al. [7] a number of intermediate ecosystem services and goods/benefits are provided by UK seabird species based on evidence from the literature or expert opinion (Table 2). Other intermediate ecosystem services (Primary production, Larval and gamete supply, Water cycling, Formation of physical barriers, Natural hazard regulation, Carbon sequestration) and goods/benefits (Fish feed, Fertiliser and biofuels, Ornaments and aquaria, Medicines and blue biotechnology, Healthy climate, Prevention of coastal erosion, Sea defence) were deemed not to be provided by UK seabird species and therefore are not included in Table 2. The definitions ensured that the seabird experts who were tasked with population of the matrix had a strong understanding of the definitions and their relevance to UK seabirds; example references have been included where evidence of relationships between seabirds and ecosystem service provision have been identified.

Table 2: Definitions of intermediate ecosystem services and goods/benefits and the role of UK seabird species in their provision (adapted from [7]).

\begin{tabular}{llll}
\hline $\begin{array}{l}\text { Intermediate } \\
\text { ecosystem } \\
\text { services }\end{array}$ & Definition & Role of UK seabirds & $\begin{array}{l}\text { Example } \\
\text { References }\end{array}$ \\
\hline $\begin{array}{l}\text { Nutrient } \\
\text { cycling }\end{array}$ & $\begin{array}{l}\text { The influence of coastal } \\
\text { and marine biota on the } \\
\text { movement or exchange } \\
\text { of organic and inorganic } \\
\text { matter. }\end{array}$ & $\begin{array}{l}\text { Seabirds have an influence on nutrient cycling } \\
\text { processes. They are significant consumers of primary } \\
\text { production; colonial seabirds in particular transport } \\
\text { nutrients from pelagic waters to island and coastal } \\
\text { breeding sites. The input of nutrients (e.g. nitrogen, }\end{array}$ \\
\hline
\end{tabular}




\begin{tabular}{|c|c|c|c|}
\hline & & $\begin{array}{l}\text { phosphorus) can contribute to an increase in primary } \\
\text { productivity within and or in the vicinity of the } \\
\text { breeding site. A significant fraction of the nitrogen at } \\
\text { breeding colonies is also lost as ammonia }\left(\mathrm{NH}_{3}\right) \\
\text { emission to the atmosphere and can have an impact } \\
\text { on the local ecosystem. }\end{array}$ & \\
\hline $\begin{array}{l}\text { Formation of } \\
\text { species- } \\
\text { habitat }\end{array}$ & $\begin{array}{l}\text { The contribution of } \\
\text { coastal and marine biota } \\
\text { to habitat formed by one } \\
\text { species but providing } \\
\text { suitable niches for other } \\
\text { species. }\end{array}$ & $\begin{array}{l}\text { Seabird colonies provide and enhance species and } \\
\text { habitat diversity. Several global studies have shown } \\
\text { the physical and chemical impact seabird colonies } \\
\text { can have on the terrestrial habitat, and their } \\
\text { subsequent effects on primary producers (e.g. plant) } \\
\text { and consumers (e.g. arthropods). Of particular UK } \\
\text { relevance are true burrow nesting seabird species } \\
\text { such as Atlantic puffin and Manx shearwater which } \\
\text { form burrows along sea cliffs and islands. These } \\
\text { species can make a significant physical impact to the } \\
\text { habitat by improving fertility and soil structure (i.e. } \\
\text { biopedturbation) and potentially providing a suitable } \\
\text { niche for other species to habit. }\end{array}$ & {$[32,33,34,35,36]$} \\
\hline $\begin{array}{l}\text { Formation of } \\
\text { seascape }\end{array}$ & $\begin{array}{l}\text { The contribution of } \\
\text { coastal and marine biota } \\
\text { to supporting the } \\
\text { formation of different } \\
\text { coastal and marine views } \\
\text { ('seascapes'). }\end{array}$ & $\begin{array}{l}\text { Seabird colonies are part of the seascape. Colonial } \\
\text { seabirds (e.g. Northern gannet, Black-legged } \\
\text { kittiwakes and auks) that nest in large numbers on } \\
\text { cliffs, and are widely distributed along the UK } \\
\text { coastline in summer, are an inherent part of the } \\
\text { seascape that is widely recognised by society. As } \\
\text { such, these species score more highly than those } \\
\text { seabird species, which may be of smaller size colony, } \\
\text { of nocturnal habits or nesting in offshore islands (e.g. } \\
\text { petrels and shearwaters). }\end{array}$ & Expert opinion. \\
\hline $\begin{array}{l}\text { Biological } \\
\text { control }\end{array}$ & $\begin{array}{l}\text { The contribution of } \\
\text { coastal and marine biota } \\
\text { to the maintenance of } \\
\text { population dynamics, } \\
\text { resilience through food } \\
\text { web dynamics, disease } \\
\text { and pest control. }\end{array}$ & $\begin{array}{l}\text { As a top predator, seabirds control marine } \\
\text { organisms. Given the role of seabirds in marine food } \\
\text { webs then they contribute to biological control as } \\
\text { they feed on fish and other marine organisms. }\end{array}$ & Expert opinion. \\
\hline $\begin{array}{l}\text { Waste } \\
\text { breakdown } \\
\text { and } \\
\text { detoxification }\end{array}$ & $\begin{array}{l}\text { The presence of coastal } \\
\text { and marine biota which } \\
\text { have the potential to } \\
\text { remove anthropogenic } \\
\text { contaminants and organic } \\
\text { inputs. }\end{array}$ & $\begin{array}{l}\text { Seabirds play an important role in waste breakdown. } \\
\text { Many seabird species are reliant on offal and } \\
\text { discarded fish for their survival, in particular } \\
\text { Northern gannets, Northern fulmars, large gull } \\
\text { species and skuas. These scavenging birds } \\
\text { contribute, albeit at low levels, to waste breakdown } \\
\text { at sea and around harbours, and thus enable species } \\
\text { lower down the food web to feed on organic inputs. } \\
\text { This service is mostly provided by scavenging gulls; } \\
\text { there is indirect evidence that Herring gull and } \\
\text { Lesser black-backed gull, make a significant } \\
\text { contribution to this service by breaking down and } \\
\text { removing organic matter at landfill sites. }\end{array}$ & {$[37,38,39]$} \\
\hline $\begin{array}{l}\text { Goods/ } \\
\text { Benefits }\end{array}$ & Definition & Role of UK seabirds & $\begin{array}{l}\text { Example } \\
\text { References }\end{array}$ \\
\hline $\begin{array}{l}\text { Food (wild, } \\
\text { farmed) }\end{array}$ & $\begin{array}{l}\text { Extraction of coastal and } \\
\text { marine biota for human } \\
\text { consumption. }\end{array}$ & $\begin{array}{l}\text { Seabirds are a source of food. Eggs and seabird } \\
\text { hunting for human consumption were a source of } \\
\text { subsistence for UK coastal communities until the } \\
\text { Seabird Preservation Act } 1869 \text { and the Wild Birds } \\
\text { Protection Act } 1954 \text { made the shooting and taking of } \\
\text { seabirds' eggs illegal. However, there continues to } \\
\text { be a licenced hunt of young Northern gannet (also } \\
\text { called gugas) on the Island of Sula Sgeir; gugas are } \\
\text { consumed by the habitants of Ness, the northern } \\
\text { district of the Isle of Lewis (Scotland). Except for this }\end{array}$ & {$[40]$} \\
\hline
\end{tabular}


localised peculiarity, this good/benefit is not relevant

at the UK scale.

\begin{tabular}{ll}
\hline Waste burial / & Contribution of coastal \\
removal / & and marine biota to \\
neutralisation & achieving pre-defined \\
& policy standard related to \\
& waste levels in water by \\
& natural waste burial, \\
& removal and \\
& neutralisation.
\end{tabular}

Tourism and Benefits from recreation, nature leisure driven by coastal

watching seascapes and their associated coastal and marine biota.

\begin{abstract}
Seabirds are natural scavengers and they contribute towards this good/benefit by recycling organic matter (e.g. discarded fish and offal) back into the marine ecosystem. This good/benefit is provided by the scavenging gull species, Northern gannets and skuas. Herring gull and Lesser black-backed gull make a significant contribution to this good/benefit to society by breaking down and removing organic matters at landfill sites. These species can travel from coastal colonies to inland landfill sites to exploit this food source.
\end{abstract}

Seabird species, as contributors to the natural UK

$[41,42,43,44]$

$[37,38,39]$ seascape provides significant contributions in the form of tourism and in particular nature watching. For example, gull species are synonymous with the characteristic UK seaside. In addition, both Northern gannet and Atlantic puffin contribute to this good/benefit as they are charismatic species, and found in relatively large numbers around the coast. Species which are observed in lower numbers or breeding further offshore are considered to contribute less to this good/benefit (such as the petrels and skuas). Literature on site management and policy links seabirds to tourism and recreation.

\begin{tabular}{|c|c|c|c|}
\hline $\begin{array}{l}\text { Spiritual and } \\
\text { cultural } \\
\text { wellbeing }\end{array}$ & $\begin{array}{l}\text { Ability to enjoy preferred } \\
\text { lifestyle, culture, } \\
\text { heritage, folklore, } \\
\text { religion, creative } \\
\text { inspiration, and } \\
\text { spirituality; sense of place } \\
\text { (use-driven) based on } \\
\text { ecosystem aspects. }\end{array}$ & $\begin{array}{l}\text { Seabird species form part of the seascape and } \\
\text { therefore may contribute to spiritual and cultural } \\
\text { wellbeing. }\end{array}$ & Expert opinion. \\
\hline $\begin{array}{l}\text { Aesthetic } \\
\text { benefits }\end{array}$ & $\begin{array}{l}\text { Enjoyment of the beauty } \\
\text { of coastal and marine } \\
\text { seascapes. }\end{array}$ & $\begin{array}{l}\text { Seabirds form part of the natural UK seascape and } \\
\text { therefore make significant contributions to aesthetic } \\
\text { benefits. Species which are coastal and/or found in } \\
\text { larger colonies are likely to provide more of this } \\
\text { good/benefit than those that are observed in lower } \\
\text { densities further offshore. }\end{array}$ & Expert opinion. \\
\hline $\begin{array}{l}\text { Education, } \\
\text { research }\end{array}$ & $\begin{array}{l}\text { Enjoyment of formal and } \\
\text { informal education, } \\
\text { research and science, } \\
\text { knowledge systems, etc. } \\
\text { in which coastal and } \\
\text { marine biota play a role } \\
\text { and are a source of } \\
\text { information. }\end{array}$ & $\begin{array}{l}\text { UK seabird species have historically been well } \\
\text { studied and therefore all have contributed to this } \\
\text { good/benefit. }\end{array}$ & [27] \\
\hline $\begin{array}{l}\text { Health } \\
\text { benefits }\end{array}$ & $\begin{array}{l}\text { Relate to human physical } \\
\text { and psychological health } \\
\text { benefits associated with } \\
\text { the direct and indirect } \\
\text { use of the coastal and } \\
\text { marine environment. }\end{array}$ & $\begin{array}{l}\text { All seabird species are deemed to contribute to } \\
\text { physical health benefits (e.g. exercise from physical } \\
\text { activity). Some species are deemed to contribute } \\
\text { and reinforce positive psychological and mental } \\
\text { health benefits both from the pursuit of activities } \\
\text { (e.g. recreation, education) and through existence } \\
\text { values that reinforce connections to the natural } \\
\text { world. }\end{array}$ & Expert opinion. \\
\hline
\end{tabular}




\subsection{Population of the UK seabird matrix.}

The matrix (Figure 2) was populated based on a combination of expert opinion and knowledge of the existing literature. For this purpose, two independent teams of marine ornithological experts, based at the University of Hull and the University of Aberdeen, were tasked with completing the matrix with guidance from the authors of this paper. A set of explanatory notes were produced by each team which documented the reasons why particular scores were assigned. The shading of each cell represents the relative importance of each species in providing the respective intermediate ecosystem service or good/benefit (darker being more important, lighter less important). Some seabird species are more important than others in providing a particular intermediate ecosystem service or good/benefit and therefore scores should be interpreted within the context of all the seabird species assessed i.e. scores for individual intermediate ecosystem services and goods/benefits are relative between species up and down the columns in the matrix. The number within each cell relates to the level of confidence in the underlying evidence. Following [1], where there was scientific, UK-relevant, peer-reviewed evidence establishing a link between a feature and an intermediate ecosystem service or good/benefit, the level of confidence was rated 3. A confidence level of 2 indicates support from non-peer reviewed grey literature (such as site management reports) or overseas literature that was not specifically relevant to either the UK or the particular species (e.g. a closely related species). Where the evidence was based purely on expert opinion, this was given a confidence rating of 1 . This score also applies to findings that are so obvious there are unlikely to be published papers to such an effect, for example seabird species make zero contribution towards the delivery of the intermediate ecosystem service 'primary production'.

\subsection{Combination of matrices based on a set of rules}

The results from each independent team of experts were combined based on a series of combination rules (Table 3). This provides a sense check of the assessment, ensures that an objective approach is used to combine potentially differing results, and provides a clear 'paper trail' of any changes that were made. The rules for combining multiple matrices were developed specifically for this paper, and thus strengthen the transparency of the established matrix approach.

Table 3: Rules for combining multiple matrices.

\begin{tabular}{|c|l|c|c|}
\hline \multicolumn{2}{|l|}{ Rules for combining multiple matrices } & \multicolumn{2}{|c|}{ Examples } \\
\cline { 3 - 4 } 2 & $\begin{array}{l}\text { Matrix 1 } \\
\text { (M1) }\end{array}$ & $\begin{array}{c}\text { Matrix 2 } \\
\text { (M2) }\end{array}$ & $\begin{array}{c}\text { Combined } \\
\text { (M1 x M2) }\end{array}$ \\
\hline 2 & $\begin{array}{l}\text { If the contribution (colour) is the same in M1 and M2 select the contribution } \\
\text { (contribution (colour) with the highest confidence score }\end{array}$ & 3 \\
\hline 3 & $\begin{array}{l}\text { If contribution (colour) is different (by more than one shade) between } \\
\text { M1 and M2 and the confidence score is the same then average the } \\
\text { contribution }\end{array}$ & 2 & 3 \\
\hline 4 & $\begin{array}{l}\text { If contribution (colour) is different (by one shade) and the confidence } \\
\text { score is the same then select the lower score (conservative approach) }\end{array}$ & 1 & 1 \\
\hline 5 & $\begin{array}{l}\text { If contribution (colour) has only been scored on one matrix then use this } \\
\text { contribution (colour) and its associated confidence score in the } \\
\text { combined matrix }\end{array}$ & 1 & 1 \\
\hline
\end{tabular}

\subsection{Sense-check and subsequent refinement of the matrix}

The draft matrix was circulated to external seabird experts within statutory bodies and their ornithological consultants to provide a further 'sense check' of the matrix and feedback on both the 
approach and the initial findings. Those who commented did so on the basis of expert judgement rather than formal peer-review. Fine-tuning amendments to ecosystem service scores (contribution and confidence levels) were made as a result of the feedback across five classifications, principally 'nutrient cycling', 'formation of seascape' and 'formation of species habitat', with minor amendments to scores for 'waste breakdown and detoxification' and 'food (wild, farmed)' resulting in the production of a final seabird matrix (Figure 2). Further details of the 'sense check' process are presented in [14].

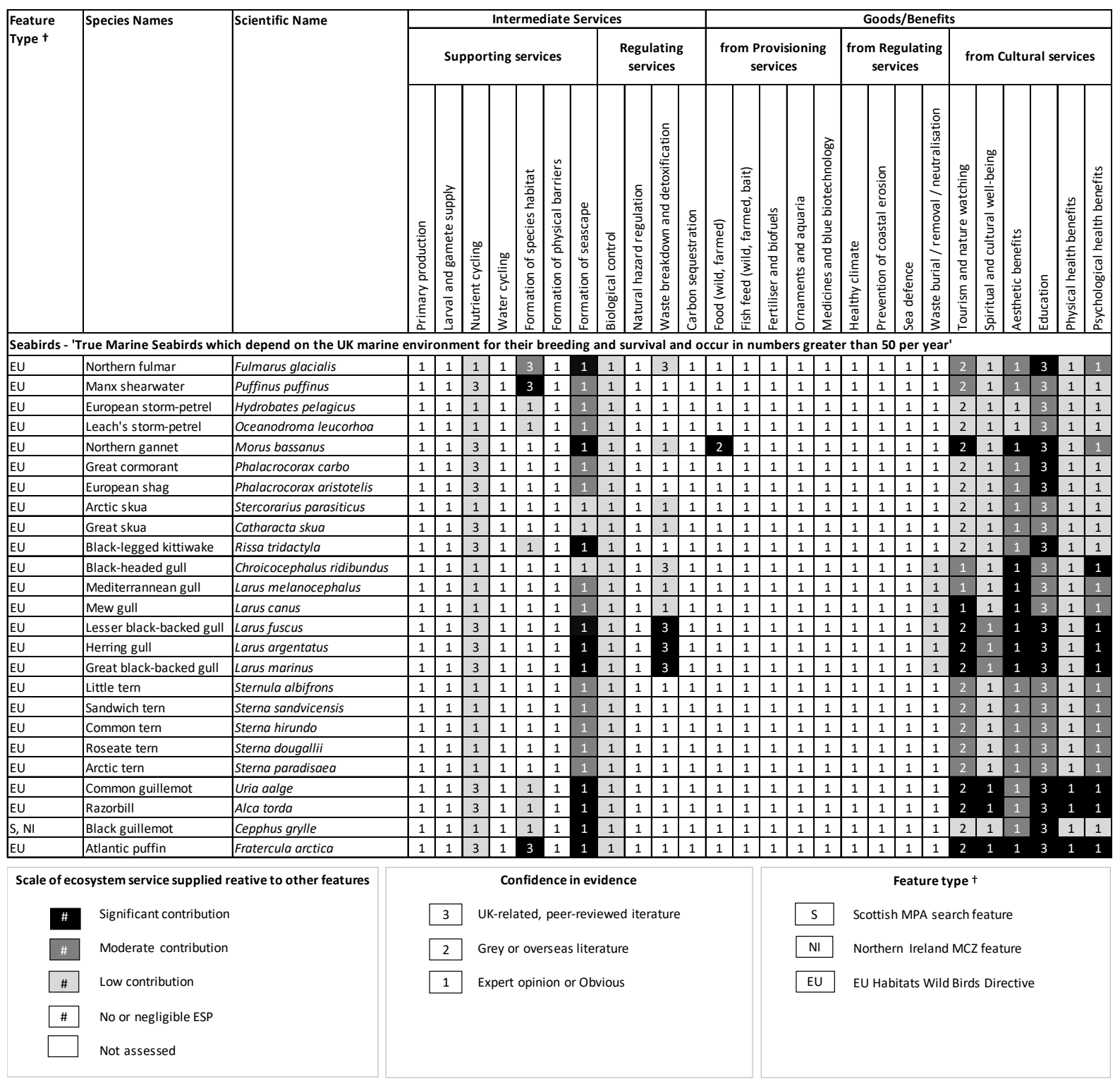

Figure 2: Relative importance of protected UK breeding seabirds in providing intermediate ecosystem services and goods/benefits.

\subsection{Case Studies}

In order to further investigate the results, the matrix (Figure 2) was applied to four existing UK MPA case study sites (Figure 3). All four case study sites are designated as Special Protected Areas (SPAs) under the EU Wild Birds Directive (79/409/EEC) or as a proposed SPA (pSPA) for an extension to an existing SPA site in the case of Flamborough and Filey Coast pSPA. Each site includes features listed under both Article 4.1 (by supporting populations of European importance of species listed in Annex I 
of the Directive) and Article 4.2 (by regularly supporting a seabird assemblage greater than 20,000 seabirds) [45]. A description of each case study site is provided in Table 4, including an assessment of the current conservation status and site management. Site specific seabird matrices for the four case study sites are included as supplementary material, with the findings summarised in the text below. Further developments and applications of the matrix are discussed in Section 4.

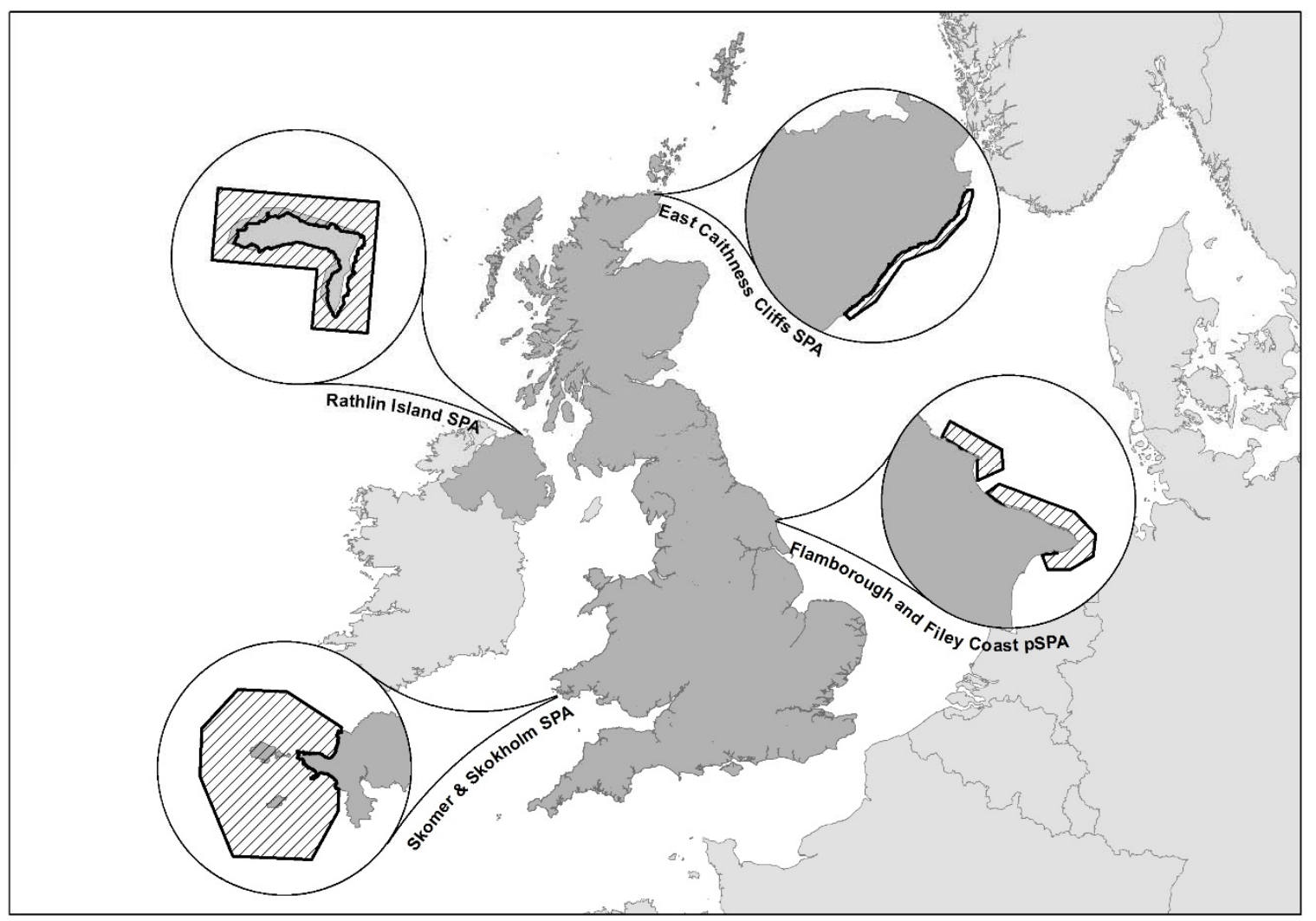

Figure 3: Case study sites used for application of the UK seabird matrix. 
Table 4: A description of case study sites.

\begin{tabular}{|c|c|c|c|c|c|c|c|}
\hline Site (Country) & $\begin{array}{l}\text { Date of } \\
\text { Designation }\end{array}$ & $\begin{array}{l}\text { Key Habitat } \\
\text { Types }\end{array}$ & $\begin{array}{l}\text { Qualifying seabird } \\
\text { species under } \\
\text { Article } 4.1\end{array}$ & $\begin{array}{l}\text { Qualifying seabird species } \\
\text { and assemblage under } \\
\text { Article } 4.2\end{array}$ & Current Conservation Status & $\begin{array}{l}\text { Site } \\
\text { Management }\end{array}$ & Key References \\
\hline $\begin{array}{l}\text { East Caithness } \\
\text { Cliffs SPA } \\
\text { (Scotland). }\end{array}$ & $\begin{array}{l}\text { March 1996, } \\
\text { extended } \\
2009 .\end{array}$ & $\begin{array}{l}\text { Old Red } \\
\text { Sandstone } \\
\text { sea cliffs. }\end{array}$ & $\begin{array}{l}\text { Common } \\
\text { guillemot, Herring } \\
\text { gull, Black-legged } \\
\text { kittiwake, } \\
\text { Razorbill, and } \\
\text { European shag. }\end{array}$ & $\begin{array}{l}\text { 300,000 individual seabirds } \\
\text { including Atlantic puffin, } \\
\text { Great black-backed gull, } \\
\text { Great cormorant, Northern } \\
\text { fulmar, Razorbill, Common } \\
\text { guillemot, Black-legged } \\
\text { kittiwake, Herring gull and } \\
\text { European shag. }\end{array}$ & $\begin{array}{l}\text { Common guillemot and Razorbill are } \\
\text { considered in favourable conservation } \\
\text { status, whilst Herring gull, Black-legged } \\
\text { kittiwake and European shag are } \\
\text { considered to be in unfavourable status } \\
\text { [43]. The seabird assemblage is } \\
\text { considered to be in favourable } \\
\text { conservation status [43]. }\end{array}$ & $\begin{array}{l}\text { Scottish Natural } \\
\text { Heritage } \\
\text { No management } \\
\text { plan. }\end{array}$ & {$[24,25,43,46,47]$} \\
\hline $\begin{array}{l}\text { Flamborough } \\
\text { and Filey Coast } \\
\text { pSPA. }\end{array}$ & $\begin{array}{l}\text { March 1993, } \\
\text { extension to } \\
\text { existing SPA } \\
\text { proposed } \\
2014 .\end{array}$ & $\begin{array}{l}\text { Coastal chalk } \\
\text { sea cliffs. }\end{array}$ & $\begin{array}{l}\text { Black-legged } \\
\text { kittiwake, } \\
\text { Northern gannet, } \\
\text { Common } \\
\text { guillemot and } \\
\text { Razorbill. }\end{array}$ & $\begin{array}{l}\text { 215,000 individual seabirds } \\
\text { including Northern fulmar, } \\
\text { Atlantic puffin, Herring gull, } \\
\text { European shag and Great } \\
\text { cormorant. }\end{array}$ & $\begin{array}{l}\text { Black-legged kittiwake numbers have } \\
\text { declined since the } 1980 \text { s and are now } \\
\text { considered in unfavourable status [41]. } \\
\text { All other features are considered in } \\
\text { favourable status [41]. }\end{array}$ & $\begin{array}{l}\text { European Marine } \\
\text { Site Relevant } \\
\text { Authorities } \\
\text { Group. } \\
\text { Management } \\
\text { plan. }\end{array}$ & {$[25,41,48,49,50]$} \\
\hline $\begin{array}{l}\text { Skomer and } \\
\text { Skokholm SPA } \\
\text { (Wales). }\end{array}$ & $\begin{array}{l}\text { August 1982, } \\
\text { reclassified in } \\
1991 \text { and } \\
2014 .\end{array}$ & $\begin{array}{l}\text { Mixed } \\
\text { grassland, } \\
\text { maritime } \\
\text { heath } \\
\text { vegetation. }\end{array}$ & $\begin{array}{l}\text { European storm- } \\
\text { petrel. }\end{array}$ & $\begin{array}{l}394,260 \text { individual seabirds } \\
\text { including Manx shearwater, } \\
\text { Atlantic puffin, European } \\
\text { storm-petrel, Lesser black- } \\
\text { backed gull, Black-legged } \\
\text { kittiwake, Common } \\
\text { guillemot and Razorbill. }\end{array}$ & $\begin{array}{l}\text { European storm-petrel is considered to } \\
\text { be in unfavourable conservation status } \\
\text { [51]. The seabird assemblage is also } \\
\text { considered in unfavourable condition as } \\
\text { both European storm-petrel and Lesser } \\
\text { black-backed gull are considered in } \\
\text { unfavourable condition [51]. }\end{array}$ & $\begin{array}{l}\text { Natural } \\
\text { Resources Wales; } \\
\text { Wildlife Trust of } \\
\text { South and West } \\
\text { Wales. } \\
\text { Management } \\
\text { plan. }\end{array}$ & {$[25,27,42,51,52]$} \\
\hline $\begin{array}{l}\text { Rathlin Island } \\
\text { SPA (Northern } \\
\text { Ireland). }\end{array}$ & $\begin{array}{l}\text { February } \\
1999 .\end{array}$ & $\begin{array}{l}\text { Basalt and } \\
\text { chalk cliffs. }\end{array}$ & $\begin{array}{l}\text { Common } \\
\text { guillemot, } \\
\text { Razorbill and } \\
\text { Black-legged } \\
\text { kittiwake. }\end{array}$ & $\begin{array}{l}66,000 \text { individual seabirds } \\
\text { including Common } \\
\text { guillemot, Razorbill, Black- } \\
\text { legged kittiwake, Northern } \\
\text { fulmar, Mew gull, Lesser } \\
\text { black-backed gull, Herring } \\
\text { gull and Atlantic puffin. }\end{array}$ & $\begin{array}{l}\text { All three seabird species under Article } \\
4.1 \text { and the seabird assemblage listed } \\
\text { under Article } 4.2 \text { are considered in } \\
\text { favourable conservation status [ } 53] \text {. }\end{array}$ & $\begin{array}{l}\text { Royal Society of } \\
\text { Protection for } \\
\text { Birds. } \\
\text { Management } \\
\text { plan. }\end{array}$ & {$[25,27,53,54,55]$} \\
\hline
\end{tabular}




\section{Results}

\subsection{General Results}

Although top predators in the marine environment, seabird species contribute to the provision of only a small number of intermediate ecosystem services (Figure 2). Except for the 'formation of seascape', which has significant contribution scores for colonial seabirds (e.g. individuals nesting in large numbers on cliffs or on islands), seabirds appear to contribute at a low level to other intermediate ecosystem services, based on expert opinion and the evidence reviewed. Within the intermediate ecosystem services, the matrix scoring revealed some groupings of species that broadly reflected the ecological niches of the species. For example, omnivorous seabirds (species feeding on variety of type of food) such as the large gull species made similar contributions to the 'waste breakdown and detoxification' service. The grouping of species was also evident for the 'formation of species habitat' services, for which the ground-nesting species (seabirds that nest in burrows) significantly contributed to. The species grouping was further enhanced in the cultural goods/benefits, where several species of a similar ecological niche made significant contributions. In this instance, the nesting-habitat type was the key ecological factor in determining the level of contribution to cultural services: ground-nesting species that were exclusively confined to islands made lower contributions compared to seabirds occupying a broader range of nesting habitats (e.g. gull species nesting in coastal and urban areas). In simple terms, access and distribution of seabirds had the greatest influence on the cultural services that the seabirds provided. The confidence scores associated with the matrix also reflect the lack of UK peer-reviewed evidence (confidence score of 3) and thus highlights current gaps in evidence, with most scores relying on expert opinion (confidence score of 1 ) or at best UK grey literature (confidence score of 2), such as MPA site management reports in the case of 'tourism and nature watching' benefits.

\subsection{Case Study Applications}

Results from the site-specific matrices are presented as supplementary material, with the key findings summarised below.

'Formation of seascape' accounts for the principal contribution to intermediate ecosystem services by all species represented at the East Caithness Cliffs SPA, either significantly for the Common guillemot, Razorbill, Northern fulmar and Atlantic puffin, or moderately for the remaining species (Figure A; supplementary material). Other intermediate ecosystem services are largely confined to low contributions to 'nutrient cycling' and, to some extent, 'formation of species habitat'. However, it is within the six categories of cultural services where the importance of seabird species contribution to goods/benefits is most evident. While low or moderate contributions across the range are recorded for many, they are outweighed by the scale of significant contributions by the majority of species, based on both individual species and the impressive assemblages represented within the SPA.

Focussing on two of the key seabird species of interest at Flamborough and Filey Coast pSPA, Blacklegged kittiwake and Northern gannet, these species have been shown to provide a number of intermediate ecosystem services and goods/benefits (Figure B; supplementary material). In particular, Black-legged kittiwake provides a moderate contribution for the intermediate ecosystem service 'formation of seascape' and for the good/benefit 'aesthetic benefits', the contribution to these intermediate ecosystem services and goods/benefits were significant for Northern gannet, and both species made a significant contribution to the good/benefit 'education'. When looking at the wider seabird assemblage, which includes contributions from a range of seabirds including Common guillemot, Razorbill, Atlantic puffin, Northern fulmar, Herring gull, European shag and Great 
cormorant the range and significance of contribution to intermediate ecosystem services and goods/benefits provision increases.

The Skomer and Skokholm SPA and the resident seabird species make a number of significant and moderate contributions to the provision of intermediate ecosystem services and goods/benefits (Figure C; supplementary material). The presence of high levels of burrow nesting species (Manx shearwater and Atlantic puffin) provides a significant contribution of the supporting service of 'formation of species habitat'. The incidence of high numbers of nesting species such as the Atlantic puffin, Manx shearwater, Common guillemot and more transient coastal seabird species such as Lesser black-backed gull significantly and moderately contribute to the 'formation of seascape'. Within the cultural goods/benefits is the significant contribution of the listed species. For example, Atlantic puffin, Razorbill and Common guillemot all provide significant cultural goods/benefits with other species providing moderate cultural goods/benefits. This is apparent with the high level of wildlife tourism and bird watching associated with the Skomer and Skokholm SPA. For example, in 2014 there were 15,732 day visitors to Skomer between April and the end of September and 1,121 overnight guests that were based on wildlife tourism [44].

Common guillemot and Razorbill, the two species currently breeding in levels of international importance at Rathlin Island SPA, provide similar levels of intermediate ecosystem services and goods/benefits; these species have a similar ecological niche, although the population of Common guillemot at the Rathlin Island SPA is four times greater (Figure D; supplementary material). With respect to the goods/benefits provided, the contribution of these two species to cultural services was significant and this is reflected by the status of the Rathlin Island SPA as one of the Northern Ireland's most iconic tourist destinations.

\section{Discussion and Concluding Comments}

One of the first challenges was deciding which marine bird species to include in the matrix. Given the focus of the paper on UK MPAs, the seabird assemblage present within designated UK sites was chosen. It could be argued that some of the species should not have been included within this list, for example the Black-headed gull and Mediterranean gull, as they both breed inland in freshwater habitats and use the near coastline only in winter; this is also the case for the majority of seaducks, divers and grebes species which were excluded from the matrix. However, the UK breeding seabird assemblage considered in this approach, which includes species from a range of conservation concern (e.g. six UK Red-listed species and 18 Amber-listed species), is a key interest feature of many UK SPAs, thus making this approach most relevant. Furthermore, the approach is ecologically coherent in the sense that it deals with species of broadly similar ecological niches i.e. UK species nesting in coastal areas and offshore islands in summer that disperse in coastal and offshore areas during the winter months. The strength of the matrix approach employed is that it allows for a modular approach and future assessments could include a wider range of species, for example in a coastal or estuarine context, the matrix could be expanded to include seaducks, divers and grebes wintering in coastal areas and waders/waterfowl using estuaries.

The population of the matrix was based on expert opinion and evidence from peer-reviewed and grey literature, where available. The confidence scores are essential as they allow users of the matrix to understand what level of understanding and evidence is available for a particular relationship between seabird species and ecosystem service provision. However it is recognised that where possible attempts to strengthen the underlying evidence base should be pursued. 
This paper has further refined the matrix approach, with the development and application of a set of rules for combining matrices. This refinement has made the approach more objective, providing a sense check of scores produced by experts for inclusion within the assessment, and ensures that there is a transparent approach to combining multiple matrices, which is essential particularly in the context of any marine management or licencing decisions.

The results generated within this paper, provide the first known attempt to assess the relative importance of the provision of the full range of intermediate ecosystem services and goods/benefits by seabird species within the UK. A number of papers have attempted to address some of these relationships $[56,57,58]$, however the UK evidence base is currently very limited. The matrix presented here is an initial step in the process and will evolve in light of further evidence of the relationships between seabird species and ecosystem service provision.

The site specific applications of the matrix have raised a number of issues of interest to site management. For example, the impressive sights and sounds of iconic seabird species within the East Caithness Cliffs SPA contribute significantly to eco-tourism in the Moray Firth and the $165 \mathrm{~m}$ annual economic contribution from trip based spending on bird and wildlife watching in Scotland [59] - of particular value to often remote, isolated communities. Protecting access to the marine food sources upon which the livelihood of both adult birds and young chicks depend, both within and outside the SPA, must therefore be a priority to maintain and/or enhance their status through managing the intense competition for marine space and development pressures within the region.

At Flamborough and Filey Coast pSPA, Black-legged kittiwake and Northern gannet populations show contrasting trends: whilst the Black-legged kittiwake population at the site has declined rapidly since the 1980s from approximately 83,700 pairs in 1987 to 37,617 pairs in 2008 [50], the Northern gannet population has grown, from a few pairs in the 1980s, to currently over 25,000 individuals [50]. At a time when both the UK and the Flamborough and Filey Coast PSPA seabirds are declining (with the exception of Northern gannet) it is critical that every measure is taken to monitor the potential impact of offshore developments on the SPA features and that adequate mitigation is in place to safeguard the birds and their key foraging areas [25]. Indeed, there are several proposed offshore wind farm developments within the foraging range of seabirds breeding at the Flamborough and Filey Coast pSPA.

Finally, the recent $f 600,000$ investment in the upgrade of the Rathlin Island Seabird Centre demonstrates the importance of this site for local tourism. Although not of international importance at the time of designation, Black-legged kittiwake are part of the qualifying seabird assemblage with a total of 9,917 pairs [53]. This small gull species which also nests on cliffs and is easily recognisable does however contribute less significantly to cultural services at a UK level, based on expert opinion, than Common guillemot and Razorbill. However, given the size of the Black-legged kittiwake population at Rathlin Island and the display offered when nesting on cliffs, it could be argued that the contribution of Black-legged kittiwake is equal to that of Common guillemot and Razorbill at a local level. This supports the case for potentially looking at seabird groups of similar ecological niche rather than individual species, when assessing their contribution to ecosystem services and good/benefits to society. Atlantic puffin, one of the most iconic UK seabird species, also nests at the site. Despite nesting in lower numbers than Black-legged kittiwake, Common guillemot and Razorbill, and being less easily observed, the Atlantic puffin is the flagship species of the RSPB reserve. Atlantic puffin, is by far the highest scoring seabird species for cultural services, and this may reflect the RSPB's strategy to exploit the public emotional affinity with Atlantic puffin and use this species as the flagship of the seabird assemblage, such as in the Rathlin Island SPA. 
The case studies have thus demonstrated how the matrix can be applied within a local context. Under current UK legislation, there is no requirement to include ecosystem service assessments within the UK MPA network [1]. This however appears to be changing with a number of policy reforms that incorporate ecosystem service objectives. For example, the ecosystem approach is mandated by Scotland's National Marine Plan for the wider marine environment [60]. At the international scale, there is increased momentum and activity in incorporating an ecosystem service approach to guide conservation policy. The UN Convention on Biodiversity (CBD) Aichi targets were adopted in 2010 by the parties to the Convention and provide a strategy for addressing biodiversity loss, restoration and societal engagement. At its 10th meeting, the parties to the CDB [61] agreed to implement the Aichi targets and provide guidance on the updating of national biodiversity strategies. The strategy identifies that nations should "take effective and urgent action to halt the loss of biodiversity in order to ensure that by 2020 ecosystems are resilient and continue to provide essential services, thereby securing the planet's variety of life, and contributing to human well-being, and poverty eradication". This is particularly evident in Aichi Target 14 that states "By 2020, ecosystems that provide essential services, including services related to water, and contribute to health, livelihoods and well-being, are restored and safeguarded, taking into account the needs of women, indigenous and local communities, and the poor and vulnerable." [61]. Target 14 identifies that methods that map and value services should be identified through participatory processes and that outcomes should be integrated into development plans [62]. In response, the European Union subsequently developed the EU Biodiversity Strategy to 2020 which incorporates an ecosystem services approach and strongly recognises that biodiversity contributes to multiple societal benefits that should be captured to better inform planning and decision making around conservation [63].

It is advocated here that incorporating an ecosystem services approach into assessments will contribute to understanding the wider benefits provided by species of conservation importance. This could have resonance with conservation managers seeking metrics to support the engagement of civil society in the ongoing management of sites. The matrix approach can also potentially act as a decision support tool in an expanded approach to strategic and environmental impact assessment, particularly with developments and consents that interact with designated sites. Site specific adaptations of the matrix could be included within existing site management plans (e.g. the Flamborough Head European Marine Site Management Scheme), or could be included within the development of future management plans (e.g. for the East Caithness Cliffs SPA) and linked to conservation objectives.

As highlighted for Rathlin Island above, the results gained open the case for potentially assessing the species contribution at an ecological niche level rather than at species level, which will enable the inclusion of a greater number of species using the marine and coastal environment e.g. shorebirds and wildfowl, and provide a better understanding of the role of birds to intermediate ecosystem services and goods/benefits to society. If seaducks, wildfowl and waders were included in the matrix at an individual species level, this would require in excess of 100 additional rows, and a considerable amount of resources to gather and assess the evidence to populate the matrix. Focussing at the ecological niche level may be a way to address this challenge, as it would assume that bird species within a particular niche will provide the same level of intermediate ecosystem services and goods/benefits. This is highlighted as an area for further investigation below.

Feedback from field research on the matrix approach using the Moray Firth region as a test case has demonstrated a willingness for new tools to aid participative governance in exploring marine spatial planning in relation to MPAs [14]; the matrix was considered a useful tool for exploring the interdependencies of ecosystems with stakeholders and society, broadening perspectives on ecosystem complexities and vulnerabilities in the context of pressures arising from industry activities 
including those arising beyond MPAs. The ease with which the different ecosystem services were considered identifiable from the matrix, in particular the cultural services, enabled a natural exploration of the links with local habitats and species through the springboard of the matrix as a starting point for discussion. This was considered valuable in helping to reveal data gaps and how these might be addressed in stakeholder settings, including through citizen science, with the goal of further improving consideration and understanding of ecosystem service flows, trade-offs and interrelationships. Visual material to enhance understanding of the species (e.g. maps, photos) were considered to be potentially useful additions to the matrix to help bring the species to life for a general audience. The same research highlighted that working with stakeholders to examine ecosystem service flows in geographically specific areas would help to refine the attribution of matrix values which were noted by some during the consultation as either self-correlating because of the quantity of research, or subjective because of the interest of researchers focusing on particular iconic species. There is also the potential for locally driven matrices to adapt scores to their local circumstances which would reflect the importance of particular habitat and species assemblages and their associated services.

The matrix presented in this paper is only considered the first step, and it is hoped that as the evidence base develops, the matrix will evolve accordingly. A number of areas of further study have been identified that support future policy application and include:

- The potential to merge the seabird matrix, with those developed for habitats and species in the UK thus providing an integrated tool for local and regional assessment and incorporation into potential marine plans [1,12];

- The matrix could be linked to other existing matrices, such as those developed for sensitivity (pressures-MCZ/MPA features) $[64,65]$ so that ecosystem service provision can be assessed in relation to habitats and species, or linked to sensitivity to a particular pressure. This could benefit the assessment of potential impacts on conservation status from emergent or cumulative activities;

- Improving the interactivity of the matrix via the development of an online search function which would also link to the underlying evidence base, thus improving dialogue with communities over the broad range of benefits that flow from SPAs and meeting national and international biodiversity commitments;

- The matrix could be applied to assess species assemblages which may enable a semiquantitative assessment of ecosystem service provision at an individual site level based on the population numbers of each species within the assemblage and the level of service provided by each species, and

- The seabird matrix could be linked to indicators of ecosystem services $[21,22]$ and could thus provide further insight into the state, behaviour and trajectory of ecosystem service provision over time. This could inform existing and new site (and species) specific management plans; quality assessments and strategic marine planning.

Nature conservation in the UK has historically been driven by European Directives [66], with the designation of SPAs under the EU Wild Birds Directive and SACs under the EU Habitats and Species Directive. However, on 23 June 2016, the UK voted to leave the European Union ('Brexit') which now raises questions regarding the future of nature conservation and thus existing EU MPA designations in UK waters. It has been recognised by Boyes and Elliott [67] that it would be unwise for the UK to undo all the effort previously put into fulfilling the European Directives. However there is current uncertainty as to what form the Natura 2000 Directives will take in the UK once they are translated into national law under the Great Repeal Bill, recently proposed by the UK Prime Minister, or whether 
they will be repealed if they are considered to be too restrictive to economic growth. It is therefore advocated here that adopting a matrix approach could provide a valuable tool in demonstrating the wider benefits for society from Natura 2000 designations (SACs and SPAs) and MPAs. Results generated from the matrix may provide additional support for the UK Government to continue with the current monitoring and management regime for MPAs within UK waters, and thus support the ambition of achieving a UK-wide, ecologically coherent network of MPAs.

\section{Acknowledgements}

The authors wish to thank Mathew Stone (Field Ornithologist, IECS, University of Hull) and Marianna Chimienti (University of Aberdeen) for their expert input into the matrix, and Shona Thomson (IECS, University of Hull) for her GIS expertise in producing Figure 3. The authors also wish to thank three anonymous external seabird experts who provided valuable feedback following a sense check of the draft matrix. The authors are grateful for the valuable comments received on the submission to Marine Policy from two anonymous referees which have significantly strengthen the paper.

\section{References}

[1] Potts, T., Burdon, D., Jackson, E., Atkins, J.P., Saunders, J., Hastings, E. \& Langmead, O., 2014. Do marine protected areas deliver flows of ecosystem services to support human welfare? Marine Policy, 44, pp. 139-148.

[2] Costanza, R., D’Arge, R., de Groot, R.S., Farber, S., Grasso, M., Hannon, B., Limburg, K., Naeem, S., O'Neil, R.V., Paruelo, J., Raskin, R.G., Sutton, P. \& Belt, M.V.D., 1997. The value of the world's ecosystem services and natural capital. Nature, 387, pp. 253-260.

[3] Daily, G.C., 1997. Introduction: What are Ecosystem Services? In: Daily, G.C. (Ed.) Nature's Services: Societal Dependence on Natural Ecosystems. Island Press, Washington, D.C., pp. 1-10.

[4] Burdon, D., 2016. An interdisciplinary approach to marine management: Bridging the divide between natural and social sciences research. PhD by published work, University of Hull, UK. April 2016.

[5] Fisher, B., Turner, R. K. \& Morling, P., 2009. Defining and classifying ecosystem services for decision making. Ecological Economics, 68(3), pp. 643-653.

[6] Luisetti, T., Turner, R.K., Bateman, I.J., Morse-Jones, S., Adams, C. \& Fonseca, L., 2011. Coastal and marine ecosystem services valuation for policy and management: managed realignment case studies in England. Ocean \& Coastal Management, 54, pp. 212-224.

[7] Turner, R.K., Mee, L., Elliott, M., Schaafsma, M., Burdon, D., Atkins, J.P., Saunders, J., Potts, T., Jickells, T, Beaumont, N. \& Bee, E., 2015. Chapter 2. Conceptual framework. In: Turner, R.K. \& Schaafsma, M. (Eds.) Coastal zones ecosystem services: from science to values and decision making. Studies in Ecological Economics, Volume 9, Springer, Switzerland.

[8] Atkins, J.P., Burdon, D., Elliott, M. \& Gregory, A.J., 2011. Management of the marine environment: integrating ecosystem services and societal benefits with the DPSIR framework in a systems approach. Marine Pollution Bulletin, 62, pp. 215-226.

[9] UKNEA, 2011. The UK National Ecosystem Assessment: Synthesis of the key findings. UNEP-WCMC, Cambridge, UK.

[10] Turner, K., Schaafsma, M., Elliott, M., Burdon, D., Atkins, J., Jickells, T., Tett, P., Mee, L., van Leeuwen, S., Barnard, S., Luisetti, T., Paltriguera, L., Palmieri, G., \& Andrews, J., 2014. UK National 
Ecosystem Assessment Follow-on. Work Package Report 4: Coastal and marine ecosystem services: principles and practice. UNEP-WCMC, LWEC, UK.

[11] Fletcher, S., Saunders, J., Herbert, R., Roberts, C. \& Dawson, K., 2012. Description of the ecosystem services provided by broad-scale habitats and features of conservation importance that are likely to be protected by Marine Protected Areas in the Marine Conservation Zone Project area. Natural England Commissioned Reports, Number 088.

[12] Saunders, J., Potts, T., Jackson, E., Burdon, D., Atkins, J.P., Hastings, E. \& Langmead, O., 2015. Chapter 9. Linking ecosystem services of marine protected areas to benefits in human wellbeing? In: Turner, R.K. \& Schaafsma, M. (Eds.) Coastal zones ecosystem services: from science to values and decision making. Studies in Ecological Economics Volume 9, Springer, Switzerland.

[13] Marine Scotland, 2013. Planning Scotland's Seas. The Scottish Marine Protected Area Project Developing the Evidence Base for Impact Assessments and the Sustainability Appraisal. Project Ref: R/4136/1, Report No: R.2097. July 2013. http://www.gov.scot/Resource/0045/00456373.pdf

[14] Barbone, C., 2016. The value of a matrix approach for improving ecosystem service flows from Marine Protected Areas in the Moray Firth. MSc Thesis, University of Aberdeen, August 2016.

[15] Potts, T., Fang, Q., Chen, W.Q. \& Burdon, D., in prep. Comparative applications of marine matrix approaches in the UK and China: Shared learning for improved MPA management.

[16] Furness, R.W. \& Camphuysen, K., 1997. Seabirds as monitors of the marine environment. ICES Journal of Marine Science: Journal du Conseil, 54, pp. 726-737.

[17] Parsons, M., Mitchell, I., Butler, A., Ratcliffe, N., Frederiksen, M., Foster, S. \& Reid, J.B., 2008. Seabirds as indicators of the marine environment. ICES Journal of Marine Science, 65, pp. 1520-1526.

[18] Grémillet, D. \& Charmantier, A., 2010. Shifts in phenotypic plasticity constrain the value of seabirds as ecological indicators of marine ecosystems. Ecological Applications, 20, pp. 1498-1503.

[19] Frederiksen, M., Wanless, S., Harris, M.P., Rothery, P. \& Wilson, L.J., 2004. The role of industrial fisheries and oceanographic change in the decline of North Sea black-legged kittiwakes. Journal of Applied Ecology, 41, pp. 1129-1139.

[20] Cook, A.S.C.P., Dadam, D., Mitchell, I., Ross-Smith, V.H. \& Robinson, R.A., 2014. Indicators of seabird reproductive performance demonstrate the impact of commercial fisheries on seabird populations in the North Sea. Ecological Indicators, 38, pp. 1-11.

[21] Atkins, J.P., Burdon, D. \& Elliott, M., 2015. Chapter 5. Identification of a practicable set of indicators for coastal and marine ecosystem services. In: Turner, R.K. \& Schaafsma, M. (Eds.) Coastal zones ecosystem services: from science to values and decision making. Studies in Ecological Economics, Volume 9, Springer, Switzerland.

[22] Hattam, C., Atkins, J.P., Beaumont, N., Borger, T., Böhnke-Henrichs, A., Burdon, D., De Groot, R., Hoefnagel, E., Nunes, P., Piwowarczyk, J., Sergio, S. \& Austen, M., 2015. Marine ecosystem services: linking indicators to their classification. Ecological Indicators, 49, pp. 61-75.

[23] Defra, 2011. The UK Marine Policy Statement. London: The Stationery Office. March 2011.

[24] JNCC, 2016a. The management status of the UK's European Marine Sites. Spreadsheet available at www.jncc.defra.gov.uk/docs/EMS_Management_v22web.xlsx (accessed 17 September 2016). 
[25] JNCC, 2016b. Seabird Population Trends and Causes of Change: 1986-2014 Report (http://www.jncc.defra.gov.uk/page-3201). Joint Nature Conservation Committee. Updated October 2015. Accessed [30 June 2016].

[26] Easton, M.A., Aebischer N.J. Brown A.F., Hearn, R.D., Lock, L., Musgrove, A.J., Noble, D.G., Stroud, D.A. \& Gregory, R.D., 2015. Birds of Conservation Concern 4: the population status of birds in the United Kingdom, Channel Islands and Isle of Man. British Birds, 108, pp. 708-746.

[27] Mitchell, I.P., Newton, S.F., Ratcliffe, N. \& Dunn, T.E. (Eds.). 2004. Seabird Populations of Britain and Ireland: results of the Seabird 2000 census (1998-2002). Published by T. \& A.D. Poyser, London.

[28] Iason, G.R., Duck C.D. \& Clutton-Brock, T.H., 1986. Grazing and reproductive success of red deer: The effect of local enrichment by gull colonies. Journal of Animal Ecology, 55, pp. 507-515.

[29] Wright, D.G., van der Wal, R., Wanless, S. \& Bardgett, R.D., 2010. The influence of seabird nutrient enrichment and grazing on the structure and function of island soil food webs. Soil Biology and Biochemistry, 42, pp. 592-600.

[30] Riddick, S.N., Dragosits, U., Blackall, T.D., Daunt, F., Wanless, S. \& Sutton, M.A., 2012. The global distribution of ammonia emissions from seabird colonies. Atmospheric Environment, 55, pp. 319-327.

[31] Cross, A.D.P., 2014. The influence of seabird-derived nutrients on island food-webs. PhD thesis, University of Glasgow, Scotland.

[32] Furness, R.W., 1991. The occurrence of burrow-nesting among birds and its influence on soil fertility and stability. In: Meadows PS (Ed.). The environmental impact of burrowing animals and animal burrows. London, Clarendon Press. Pp. 53-67

[33] Polis, G.A. \& Hurd, S.D., 1996. Linking marine and terrestrial food webs: Allochthonous input from the ocean supports high secondary productivity on small islands and coastal land communities. The American Naturalist, 147, pp. 396-423.

[34] Anderson, B.W. \& Polis, A.G., 1999. Nutrient fluxes from water to land: Seabirds affect plant nutrient status on Gulf of California islands. Oecologia, 118, pp. 324-332.

[35] Sánchez-Piñero, F. \& Polis, G.A., 2000. Bottom-up dynamics of allochthonous input: direct and indirect effects of seabirds on islands. Ecology, 81, pp. 3117-3132.

[36] Ellis, J.C., 2005. Marine birds on land: A review of plant biomass, species richness, and community composition in seabird colonies. Plant Ecology, 181, pp. 227-241.

[37] Horton, N., Brough, T. \& Rochard, J.B.A., 1983. The importance of refuse tips to gulls wintering in an inland area of southeast England. Journal of Applied Ecology, 20, pp. 751-765.

[38] Coulson, J.C., Butterfield, J., Duncan, N. \& Thomas, C., 1987. Use of refuse dumps by adult British Herring Gulls Larus argentatus during the week. Journal of Applied Ecology, 24, pp.789-800.

[39] Ratcliffe, N., 2004. Causes of seabird population change. In: Mitchell, P.I., Newton, S.F., Ratcliffe, N. \& Dunn, T.E. (Ed.) Seabird populations of Britain and Ireland. T. \& A.D. Poyser, London, pp 407-437.

[40] Trinder, M., 2016. Population viability analysis of the Sula Sgeir gannet population. Scottish Natural Heritage Commissioned Report No. 897. 
[41] Davison, H., 2016. 2016-2021 Flamborough Head European Marine Site Management Plan. September 2016. Flamborough Head European Marine Site Management Scheme, County Hall, Beverley, UK.

[42] NRW, 2015. Proposals to extend Skokholm and Skomer Special Protection Area and rename it as Skomer, Skokholm and the Seas Off Pembrokeshire Special Protection Area. Advice to the Welsh Government and UK Government. Natural Resources Wales, June 2015, 30pp.

[43] SNH, 2015. Site details for East Caithness Cliffs SPA. [Accessed 7 October 2016] http://gateway.snh.gov.uk/sitelink/siteinfo.jsp?pa_code=8492

[44] Bueche, B., Bramwell, A., Moss, J. \& Stubbings, E, 2014. Skomer Island National Nature Reserve. Annual Report 2014. Wildlife Trust of South West Wales. Available: https://www.welshwildlife.org/wp-content/uploads/2014/07/Skomer-Annual-Report-2014-FinalPublic-Version.pdf

[45] EC, 2009. Directive 2009/147/EC of the European Parliament and of The Council of 30 November 2009 on the conservation of wild birds (codified version). Off. J. Eur. Union, L20 (2009), pp. 7-25.

[46] Swann, B., 2016. Seabird counts at East Caithness Cliffs SPA for marine renewable casework. Scottish Natural Heritage Commissioned Report No. 902. Available at http://www.snh.org.uk/pdfs/publications/commissioned reports/902.pdf.

[47] JNCC, 2016c. Natura 2000 - East Caithness Cliffs Site UK9001182, Standard Data Form For Special Protection Areas (SPA), Proposed Sites for Community Importance (pSCl), Sites of Community Importance (SCI) and for Special Areas of Conservation (SAC). Generated by the Joint Nature Conservation Committee 25 January 2016. Available at http://jncc.defra.gov.uk/pdf/SPA/UK9001182.pdf.

[48] Evans, K., 2000. Flamborough Head European Marine Site Management Scheme. December 2000. Flamborough Head Project Officer, Town Hall, Bridlington, UK.

[49] Stockdale, L., 2007. The Flamborough Head Management Plan. March 2007. Flamborough Head Project Officer, Bridlington, UK.

[50] Aitken, D., Babcock, M., Clarkson, K. \& Jackson, S., 2015. Flamborough Head and Filey Coast pSPA Seabird Monitoring Programme 2015 Report. Natural England \& Royal Society for the Protection of Birds.

[51] CCW, 2008. Core management plan including conservation objectives for Skomer and Skokholm SPA (Special Protection Area). Version 6, 2 April 2008.

https://www.naturalresources.wales/media/674164/Skomer[1].Skokholm\%20management\%20plan \%2007.pdf

[52] Stroud, D.A., Chambers, D., Cook, S., Buxton, N., Fraser, B., Clement, P., Lewis, I., McLean, I., Baker, H. \& Whitehead, S. 2001. The UK SPA network: its scope and content. Volumes 1-3. JNCC, Peterborough Available at: http://jncc.defra.gov.uk/page-1418

[53] DAERA, 2016. Department of Agriculture, Environment and Rural Affairs publications. Rathlin Special Protection Area. Accessed on 21 September 2016. https://www.daerani.gov.uk/publications/rathlin-special-protection-area 
[54] Lloyd C., Tasker M.L. \& Partridge K., 1991. The status of seabirds in Britain and Ireland. Poyser, London.

[55] DOE, 2013. Rathlin Island European Marine Site Management Scheme. Department of Environment Northern Ireland, Belfast. ISBN - 978-1-907053-58-0

[56] Green, A.J. \& Elmberg, J., 2014. Ecosystem services provided by waterbirds. Biological Reviews, 89 , pp. $105-122$.

[57] Ruiz-Frau, A., Hinz, H., Edwards-Jones, G. \& Kaiser, M.J., 2013. Spatially explicit economic assessment of cultural ecosystem services: Non-extractive recreational uses of the coastal environment related to marine biodiversity. Marine Policy, 38, pp. 90-98.

[58] Whelan, C.J., Şekercioğlu, Ç.H. \& Wenny, D.G.J., 2015. Why birds matter: from economic ornithology to ecosystem services. Journal of Ornithology, 156, pp. 227-238.

[59] Scottish Government, 2015a. The Scottish Marine Recreation and Tourism Survey Final Report. Prepared by Land Use Consultants for the Scottish Government. Available at www.gov.scot/Topics/marine/seamanagement/national/RecandTourism.

[60] Scottish Government, 2015b. Scotland's National Marine Plan - A Single Framework for Managing Our Seas. Scottish Government, Edinburgh, March 2015.

[61] Convention on Biological Diversity, 2010. Decision Adopted by the Conference of the Parties to the Convention on Biological Diversity at its 10th Meeting. $\mathrm{X} / 2$. The Strategic Plan for Biodiversity 2011-2020 and the Aichi Biodiversity Targets Available: https://www.cbd.int/doc/decisions/cop10/cop-10-dec-02-en.pdf

[62] Convention on Biological Diversity, 2016. TARGET 14 - Technical Rationale and Quick Guide. Available from: https://www.cbd.int/doc/strategic-plan/targets/T14-quick-guide-en.pdf

[63] EC, 2011. Communication from the Commission to the European Parliament, the Council, the Economic and Social Committees and the Committee of the Regions. Our life insurance, our natural capital: an EU biodiversity strategy to 2020. Brussels, 3.5.2011 COM(2011) 244 final. Available: http://eur-lex.europa.eu/legal-content/EN/TXT/?uri=CELEX:52011DC0244

[64] Tillin, H.M., Hull, S.C. \& Tyler-Walters, H., 2010. Development of a sensitivity matrix (pressuresMCZ/MPA features). Report to the Department of the Environment, Food and Rural Affairs from ABPmer, Southampton and the Marine Life Information Network (MarLIN) Plymouth: Marine Biological Association of the UK, Defra Contract no. MB0102 Task 3A, Report no. 22, London, 145 pp.

[65] Tillin, H. \& Tyler-Walters, H., 2014. Assessing the sensitivity of subtidal sedimentary habitats to pressures associated with marine activities. Phase 1 Report: Rationale and proposed ecological groupings for Level 5 biotopes against which sensitivity assessments would be best undertaken. JNCC Report.

[66] Boyes, S.J. \& Elliott, M., 2014. Marine legislation - the ultimate 'horrendogram': International law, European directives \& national implementation. Marine Pollution Bulletin, 86, pp. 39-47.

[67] Boyes, S.J. \& Elliott, M., Brexit: The marine governance horrendogram just got more horrendous! Marine Pollution Bulletin (2016), http://dx.doi.org/10.1016/j.marpolbul.2016.08.020 


\section{Supplementary Material}

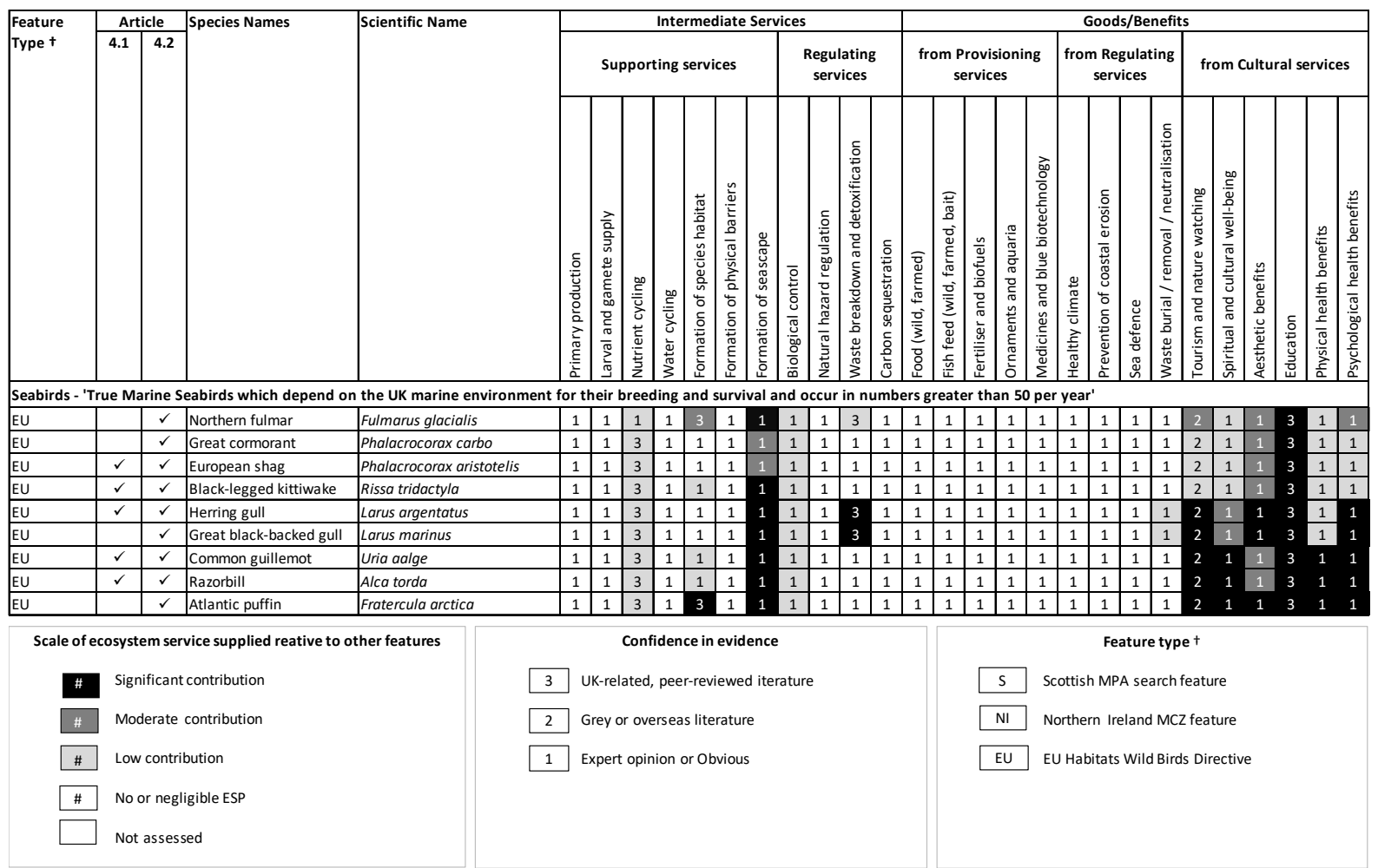

Figure A: East Caithness Cliffs SPA Seabird Matrix.

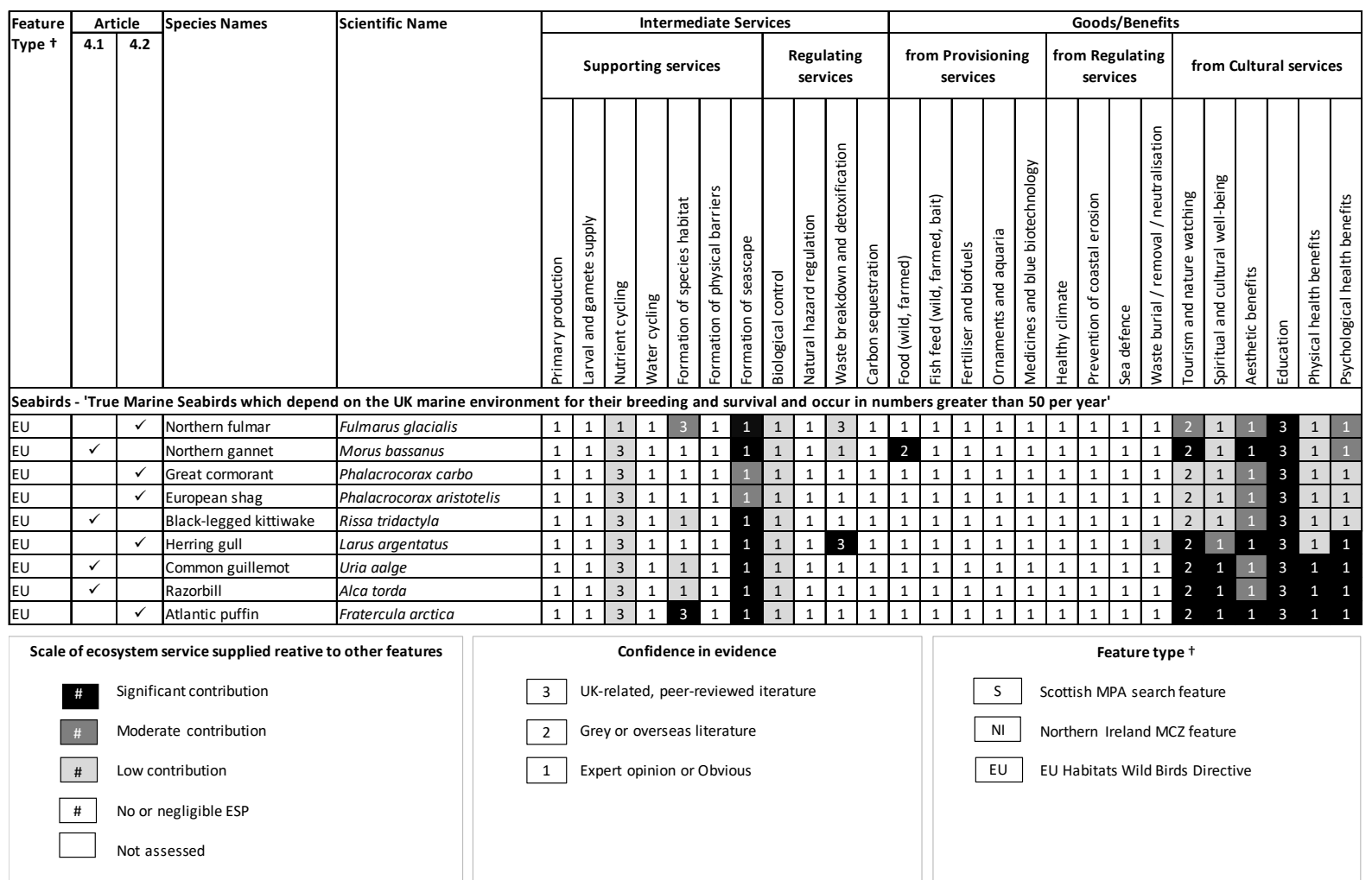

Figure B: Flamborough and Filey Coast pSPA Seabird Matrix. 


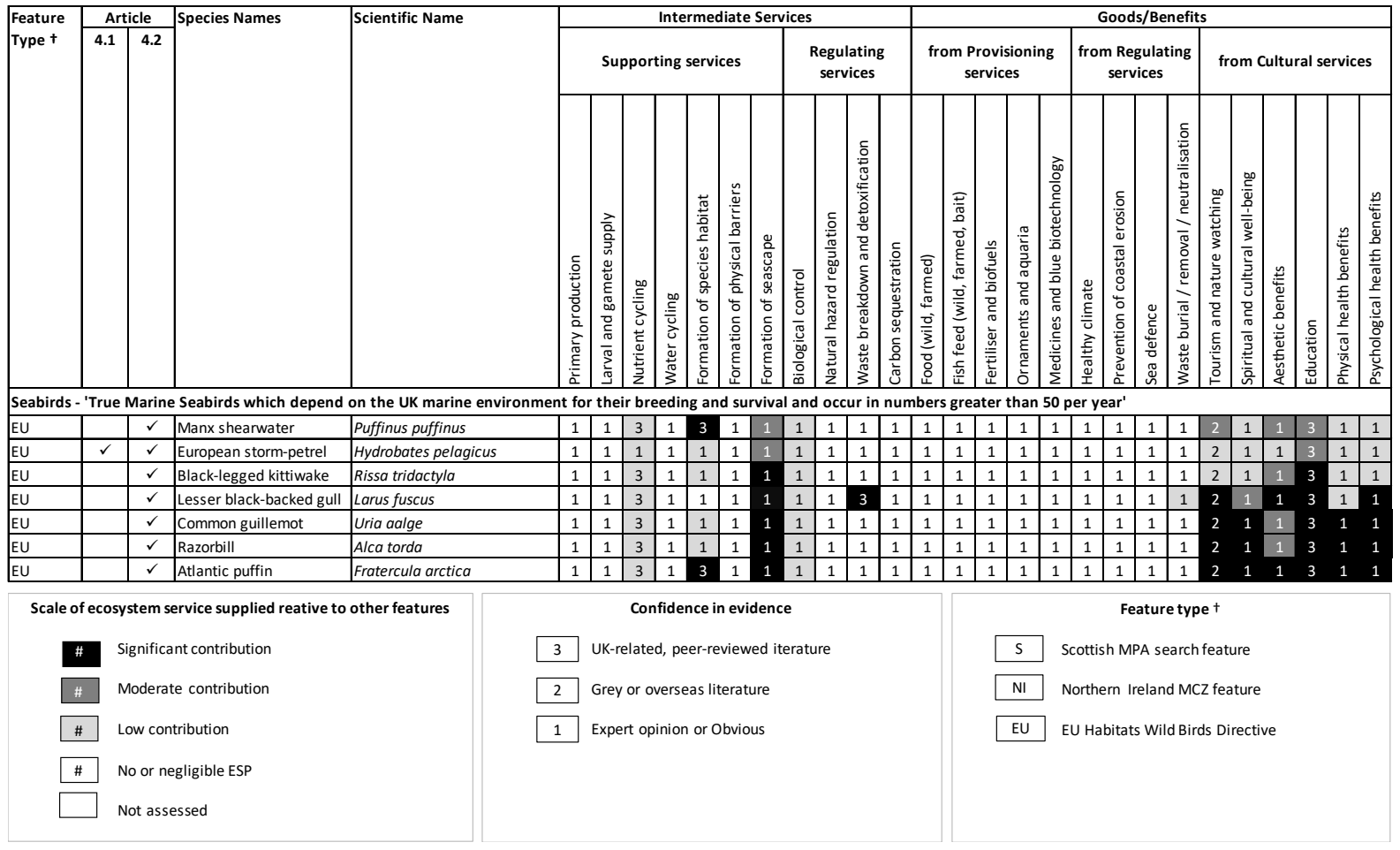

Figure C: Skomer \& Skokholm SPA Seabird Matrix.

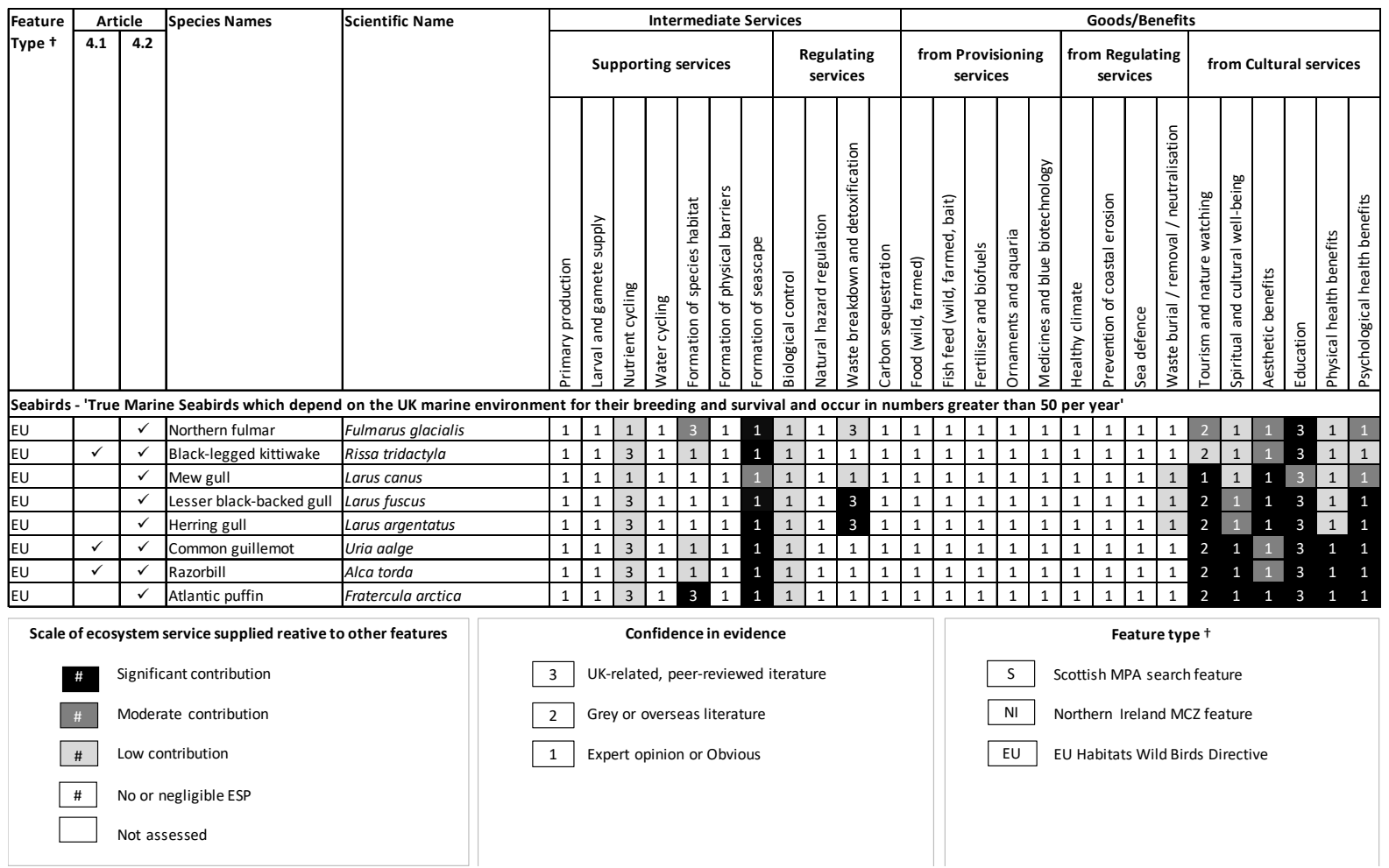

Figure D: Rathlin Island SPA Seabird Matrix. 